\title{
Factors of soil diversity in the Batumi delta (Georgia)
}

\author{
Bülent Turgut and Merve Ateş \\ Artvin Çoruh University, Faculty of Forestry, Department of Soil and Ecology, Artvin, Turkey \\ Correspondence to: Bülent Turgut (bturgut@artvin.edu.tr)
}

Received: 18 July 2016 - Published in Solid Earth Discuss.: 15 August 2016

Revised: 25 November 2016 - Accepted: 13 December 2016 - Published: 3 January 2017

\begin{abstract}
The aim of this study was to determine certain basic properties of soils in the Batumi delta (southwestern Georgia) to determine the relationships of studied properties and to identify differences with regards to these properties between different sampling sites in the delta that were selected based on the delta morphology. In this context, a total of 125 soil samples were collected from five different sampling sites, and the clay, silt and sand content of the samples were determined along with their mean weight diameter (MWD) values, aggregate stability (AS) values, amount of water retained under $-33(\mathrm{FC})$ and $-1500 \mathrm{kPa}(\mathrm{WP})$ pressure and organic matter $(\mathrm{OM})$ content. Correlation analysis indicated that clay content and OM were positively correlated with MWD, and OM was positively correlated with AS. However, the sand content was found to be negatively correlated with MWD. In addition, clay, silt and OM content were positive correlated with FC and WP. Variance analysis results determined statistically significant differences between the sampling sites with respect to all of the evaluated properties. The active delta section of the study area was characterized by high sand content, while the lower delta plain was characterized by high OM and AS values, and the upper delta plain was characterized by high MWD values, high FC and WP moisture content levels and high clay and silt content. In conclusion, it was demonstrated that the examined properties were significantly affected by the different morphological positions and usages of these different areas. These results may help with the management of agricultural lands in the Batumi delta, which has never been studied before.
\end{abstract}

\section{Introduction}

Soil is a key part of the Earth system as a control of the hydrological, erosional, biochemical and biological cycles (Brevik et al., 2015; Decock et al., 2015; Smith et al., 2015). Soil contributes to basic human needs like food, clean water and clean air, and it is a major carrier for biodiversity (Keesstra et al., 2016), a consequence of soils forming at the intersection of the atmosphere, biosphere, and lithosphere (Brevik et al., 2015). Thus, soils covering the Earth vary even on small scales in terms of their properties.

Deltas, which are one of the best examples of alluvial soils, are geomorphological structures that result from the deposition and accumulation of alluvial material at estuaries (Erinç, 2001). Owing to the wetlands and high biodiversity they harbor and to their high potential for agricultural production, deltas are areas of great ecological and agricultural significance (Imentai et al., 2015; Khai and Yabe, 2015; Gillison et al., 2016). Depending on the time of accumulation of the alluvial materials, the delta morphology consists of three distinct areas, which, starting from the coast, are the active delta area, the lower deltaic plain and the upper deltaic plain $(\mathrm{Er}-$ inç, 2001). These parts of deltas show differences in terms of soil properties (Søvik and Aagaard, 2003; Unverricht et al., 2013).

In deltas, the fact that different sections have formed at different times also leads to differences in the way these areas are utilized. The active delta section, which is the youngest section of deltas, generally lacks any notable agricultural production activity, while the upper deltaic plains, which are older in terms of their time of formation, are areas of extensive agricultural activity. The different agricultural use of different delta areas also results in the differences between their soil properties. Numerous researchers have reported that differences in the utilization of delta areas contribute to con- 
siderable differences in soil properties (Huang et al., 2012; Deng et al., 2016; Hernández et al., 2016; Madhavan et al., 2016). Conducting agricultural production in delta soils first requires reclamation activities (Krishnamoorthy et al., 2014). It is known that reclamation activities such as plowing, irrigation and fertilization cause changes in the physical (Jiao et al., 2014; Li et al., 2014) and chemical properties (Cui et al., 2012; Han et al., 2014; Jiao et al., 2014) of the soil.

The Batumi delta, which is fed with water and materials carried by the Çoruh and Adjaristsqali rivers, is one of Georgia's most important agricultural production areas. The subtropical climate of the region has promoted a diversity of agricultural production activities. Although the Batumi delta is a very important area of agricultural production, there are currently no studies that have investigated the properties of its soils. The aim of this study was (i) to determine the general properties of soils in the Batumi delta, (ii) to determine the relationships of studied properties and (iii) to compare these properties between different delta areas that are considered to be morphologically different.

\section{Material and methods}

\subsection{Study area}

The presented study was conducted in the Batumi delta, located in the south-west part of Georgia (Fig. 1). The delta covers an area of approximately 3900 ha. The delta is flat with an elevation ranging from 2 to $50 \mathrm{~m}$ above the sea level (Fig. 1). The main form of land use in the delta is agriculture, which is especially dominant in the lower deltaic plain and upper deltaic plain, while the active deltaic plain is covered by pastures. The most commonly grown crops are vegetables and tangerines. The investigated area is characterized by a humid subtropical climate, with an annual average temperature of $14.4^{\circ} \mathrm{C}$ and annual precipitation of $2718 \mathrm{~mm}$.

\subsection{Sampling pattern and analyses}

The Batumi delta was divided into five different sites based on morphological differences. The first site consisted of the active delta area (L1), while the second and third sites comprised the lower deltaic plain (L2 and L3), and the fourth and fifth sites comprised the upper deltaic plain (L4 and L5) (Fig. 2). Information on these sites is provided in Table 1. In each one of these sites, soils samples were collected at 25 different points from the surface layer $(0-20 \mathrm{~cm})$.

Soil samples were air-dried and passed through a $2 \mathrm{~mm}$ sieve. Particle size distribution was determined by the hydrometer method (Gee and Bauder, 1986), while aggregate stability (AS) for $0.25-0.5,0.50-1.00$ and $1.00-2.00 \mathrm{~mm}$ size aggregates was determined with the Yoder wet-sieving method (Kemper and Rosenau, 1986). Soil organic matter (OM) content was determined by the Walkley-Black method (Schnitzer, 1982). Mean weight diameter (MWD) was calcu- lated following Eq. (1) (Van Bavel, 1950):

$\mathrm{MWD}=\sum_{i=1}^{n} x_{i} y_{i}$

where $y_{i}$ is the proportion of each size class by weight with respect to the total sample and $x_{i}$ is the mean diameter of the size classes (mm).

Analysis was performed in three replications for each soil sample. Descriptive statistics, including averages, standard deviation, minimum and maximum values, and the coefficient of variation were determined for all the studied soil properties. The correlation analysis was performed to assess the relationships between variables; the analysis of variance was applied to determine the differences between the sampling sites. JMP 5.0 package software was used to conduct statistical analyses (JMP, 2007).

\section{Results}

\subsection{Descriptive statistics}

Table 2 shows the descriptive statistic results regarding the soil properties examined in study. The clay content of the soils within the study area varied between 1.47 and $24.21 \%$, with a mean level of $8.91 \%$; in this respect, the clay content constituted the lowest fraction in the soils. The silt content of the soils varied between 4.90 and $53.41 \%$, with a mean level of $29.13 \%$. The sand content of the soils varied between 36.04 and $92.11 \%$, with a mean level of $92.11 \%$. Sand content thus constituted the highest fraction in the soils within the study area. The MWD of the aggregates within the study area varied between 0.26 and $1.02 \mathrm{~mm}$, while the average MWD was calculated as $0.64 \mathrm{~mm}$.

The AS of the studied soils was separately calculated for each class of aggregate size. For the largest aggregate size class (1.00-2.00 mm, $\mathrm{AS}_{1}$ ), AS values varied between 40.08 and $95.40 \%$, while the mean $\mathrm{AS}_{1}$ level was $82.06 \%$, which indicated "very good" AS (Dilkova et al., 2002). For the second largest aggregate size class $\left(0.50-1.00 \mathrm{~mm}, \mathrm{AS}_{2}\right), \mathrm{AS}$ values varied between 32.88 and $95.68 \%$, while the mean $\mathrm{AS}_{2}$ level was $82.06 \%$, which indicated "very good" AS. For the smallest aggregate size class $\left(0.25-0.50 \mathrm{~mm}, \mathrm{AS}_{3}\right), \mathrm{AS}$ values varied between 58.56 and $95.31 \%$, while the mean $\mathrm{AS}_{3}$ level was $86.01 \%$, which again indicated "very good" AS.

The moisture content retained by the soils at $-33 \mathrm{kPa}$ (i.e., the soil field capacity, FC) varied between 5.29 and $57.10 \%$ of the soil mass, with a mean level of $29.84 \%$. On the other hand, the moisture content retained by the soils at $-1500 \mathrm{kPa}$ (i.e., the soil wilting point, WP) varied between 2.92 and $49.32 \%$ of the soil mass, with a mean level of $22.84 \%$. The values determined for both moisture constants were higher than the values normally observed for the predominant soil texture class found in the study area (Karaman et al., 2007). 
Table 1. Morphological position, land use type and location of sampling sites.

\begin{tabular}{|c|c|c|c|c|c|c|}
\hline \multirow[t]{2}{*}{$\begin{array}{l}\text { Sampling } \\
\text { site }\end{array}$} & \multirow[t]{2}{*}{$\begin{array}{l}\text { Morphological } \\
\text { position }\end{array}$} & \multirow[t]{2}{*}{ Land use type } & \multirow[t]{2}{*}{ Gradient } & \multirow[t]{2}{*}{$\begin{array}{r}\text { Elevation } \\
(\mathrm{m})\end{array}$} & \multicolumn{2}{|c|}{$\begin{array}{l}\text { Coordinate } \\
\text { (UTM, 37T) }\end{array}$} \\
\hline & & & & & North & East \\
\hline L1 & Active delta & Pasture & Flat & 3 & 4608002 & 715853 \\
\hline L2 & Lower deltaic plain & Pasture & Flat & 8 & 4607475 & 715986 \\
\hline L3 & Lower deltaic plain & Orchard (tangerine) and pasture & Flat & 8 & 4611062 & 717270 \\
\hline L4 & Upper deltaic plain & Orchard (tangerine) & Flat & 8 & 4606381 & 715325 \\
\hline L5 & Upper deltaic plain & Orchard (tangerine) and vegetable fields & Flat & 18 & 4609295 & 719522 \\
\hline
\end{tabular}

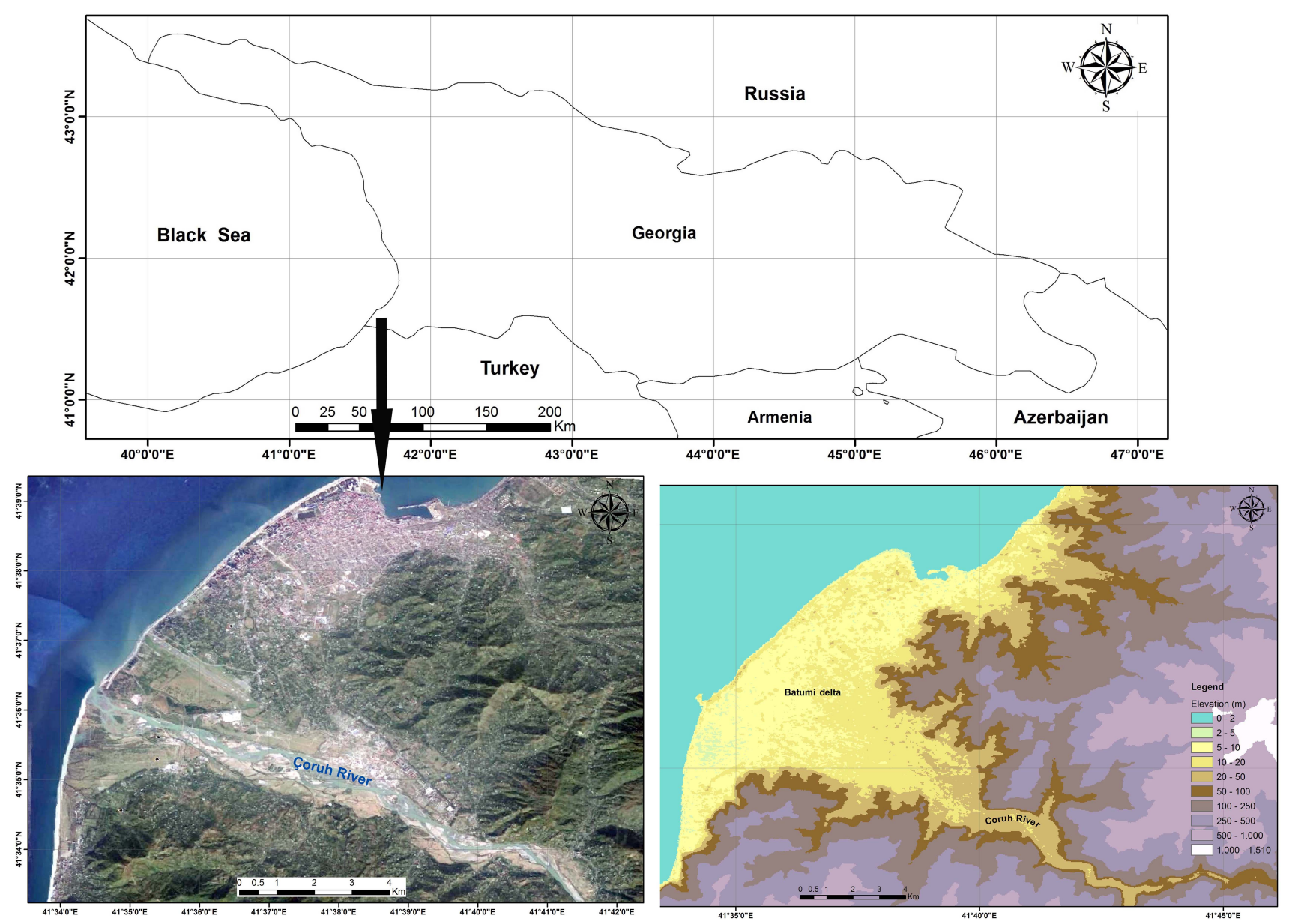

Figure 1. Location of the Batumi delta and digital elevation model (DEM) of study area.

The OM content of the soils varied between 0.37 and $5.63 \%$, with a mean level of $2.53 \%$. It was determined that this level of OM content is relatively high for soils belonging to the sandy loam texture class (Marchetti et al., 2012).

Among the different properties that were examined, the lowest variation coefficient was calculated for the $\mathrm{AS}_{3}$ values $(9.45 \%)$, while the highest variation coefficient was calculated for the clay content $(54.70 \%)$. In other words, the most homogenous property in the study areas was $\mathrm{AS}_{3}$, while the most heterogeneous one was clay content. With respect to the particle size distribution, clay content was the most heterogeneous soil property, and sand content was the most homogeneous soil property. With respect to $\mathrm{AS}, \mathrm{AS}_{1}$ was the most heterogeneous soil property, and $\mathrm{AS}_{3}$ was the most homogeneous soil property. With respect to moisture constants, FC was found to be a more homogenous property. 


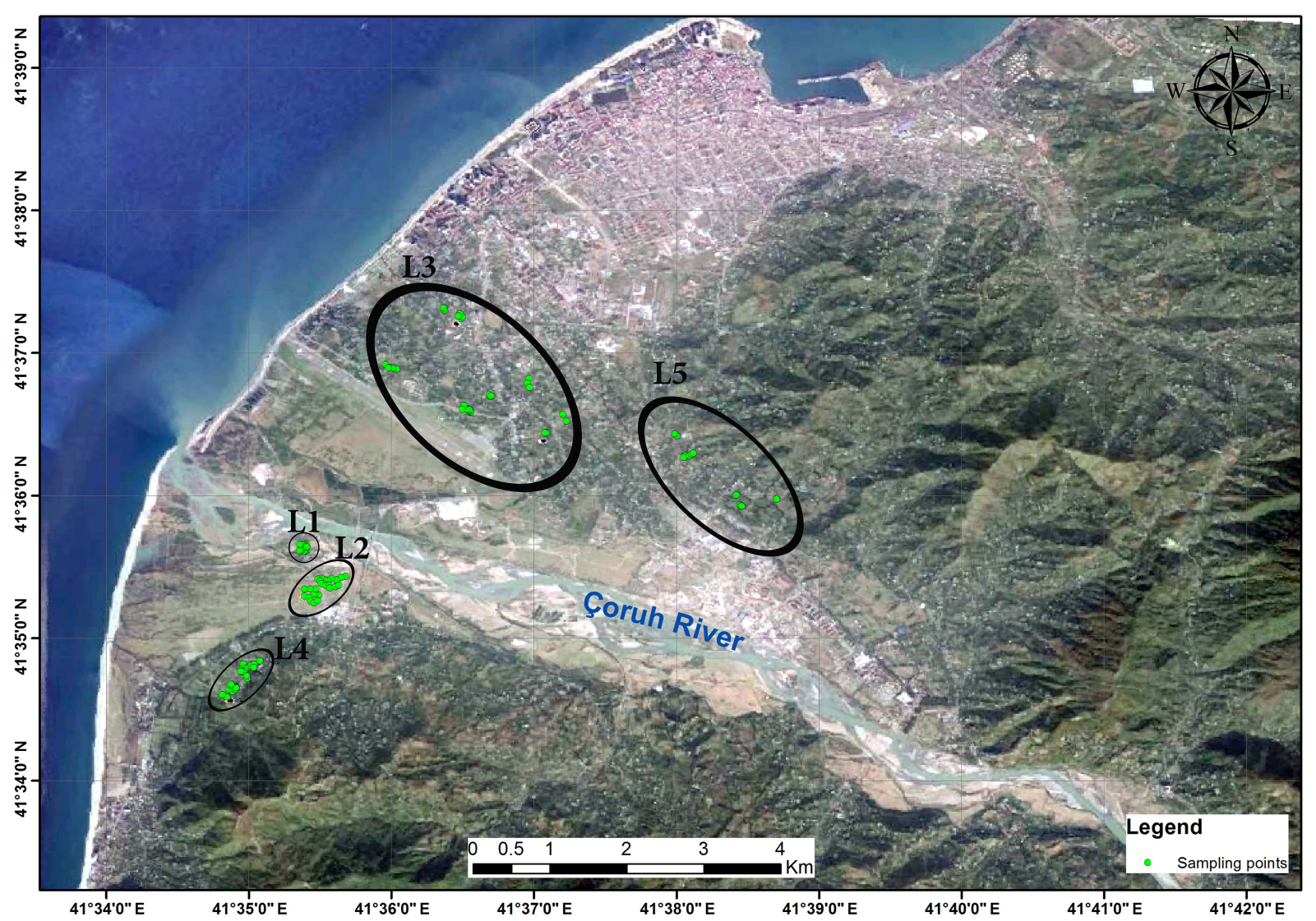

Figure 2. Location of the sampling points in the Batumi delta (L1, L2, L3, L4 and L5 represent the sampling sites. L1 is located in the active delta, L2 and L3 in lower deltaic plain, and L4 and L5 in upper deltaic plain).

Table 2. Summary statistics of soil properties.

\begin{tabular}{lrrrrr}
\hline Variable & Minimum & Maximum & Mean & $\begin{array}{r}\text { Standard } \\
\text { deviation }\end{array}$ & $\begin{array}{c}\text { Coefficient of } \\
\text { variation (\%) }\end{array}$ \\
\hline Clay & 1.47 & 24.21 & 8.91 & 4.87 & 54.70 \\
Silt & 4.90 & 53.41 & 29.13 & 9.07 & 31.14 \\
Sand & 36.04 & 92.11 & 61.42 & 12.22 & 19.90 \\
OM & 0.37 & 5.63 & 2.53 & 1.25 & 49.49 \\
MWD & 0.26 & 1.02 & 0.64 & 0.19 & 30.13 \\
SS $_{1}$ & 40.08 & 95.40 & 82.06 & 12.94 & 15.77 \\
SS $_{2}$ & 32.88 & 95.68 & 82.69 & 12.38 & 14.97 \\
SS $_{3}$ & 58.56 & 95.31 & 86.01 & 8.13 & 9.45 \\
FC & 5.29 & 57.10 & 29.84 & 9.08 & 30.44 \\
WP & 2.92 & 49.32 & 22.84 & 8.43 & 36.90 \\
\hline
\end{tabular}

$\mathrm{MWD}$, mean weight diameter; $\mathrm{OM}$, organic matter content; $\mathrm{AS}_{1}$, aggregate stability of

$1.00-2.00 \mathrm{~mm}$ aggregate size; $\mathrm{AS}_{2}$, aggregate stability of $0.50-1.00 \mathrm{~mm}$ aggregate size; $\mathrm{AS}_{3}$, aggregate stability of $0.25-0.50 \mathrm{~mm}$ aggregate size; $\mathrm{FC}$, water retention in $-33 \mathrm{kPa}$; WP, water retention in $-1500 \mathrm{kPa}$.

\subsection{Correlation analysis results}

The results for the correlation analysis between the examined soil characteristics are shown in Table 3. Based on the analysis results, positive correlation was identified between MWD and the clay and OM of soils, while negative correlation was identified between MWD and sand content. A positive correlation was identified as well between OM and AS. It was also observed that the effect of OM on AS values decreased in parallel to the decrease in aggregate size. 


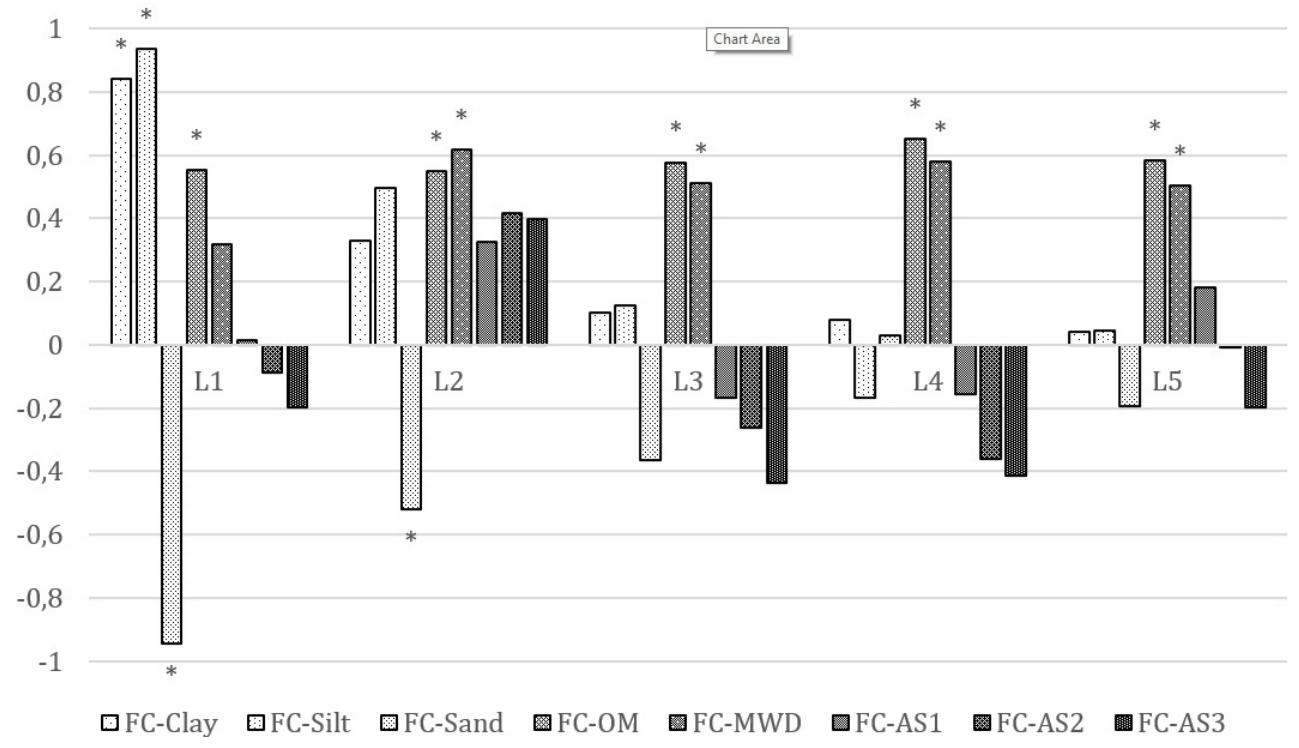

Figure 3. The correlation coefficients between field capacity and other soil properties in sampling areas (L1, L2, L3, L4 and L5 are the sampling sites; see Fig. 2). ${ }^{*}$ Significant relationship at $\alpha=0.01$.

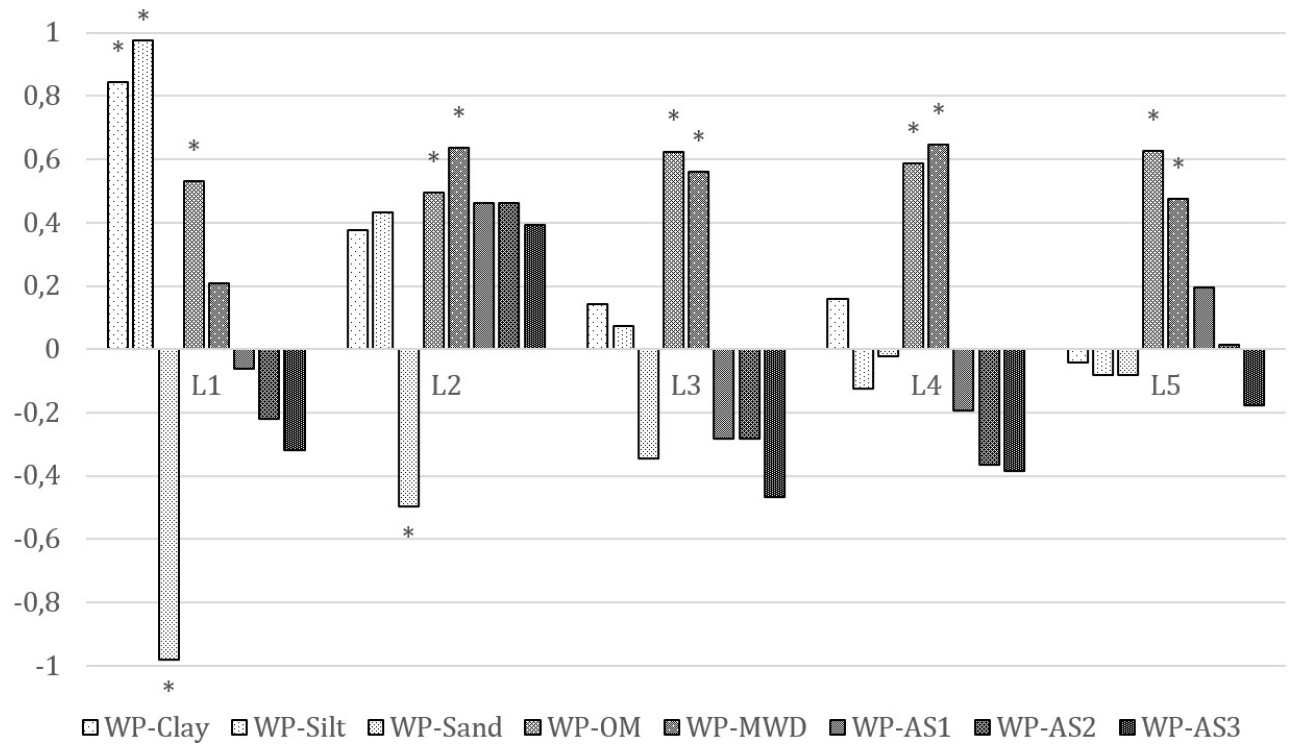

Figure 4. The correlation coefficients between wilting point and other properties in sampling areas (L1, L2, L3, L4 and L5 are the sampling sites; see Fig. 2). ${ }^{*}$ Significant relationship at $\alpha=0.01$.

Correlation analysis results evaluating the relationship between the soil water constants and the soil characteristics in question indicated statistically significant relationships between all the soil characteristics on the one hand and the FC and WP on the other.

These relationships vary among sampling areas both in direction and strength. It was determined that the clay, silt and sand contents were more effective in the water retention in L1, where the OM was lower. However, in the areas with higher $\mathrm{OM}$ and aggregation, the effect of the grain size distri- bution decreased and the effect of the OM and the MWD, albeit significantly, increased on FC and WP. In addition, evaluation of the correlation coefficients showed that the greatest effect of MWD was on FC and WP.

According to the factor analysis results, factors 1 and 2 explain 45.56 and $24.63 \%$ of the variance in the soil properties, respectively (Fig. 5). Among the soil properties, clay content $(R=0.545), \mathrm{OM}(R=0.612)$, MWD $(0.736)$, $\mathrm{AS}_{1}(R=0.750), \mathrm{AS}_{2},(R=0.654), \mathrm{AS}_{3}(R=0.505), \mathrm{FC}$ $(\mathrm{R}=0.923)$ and WP $(\mathrm{R}=0.866)$, which were the most impor- 
Table 3. Correlation matrix of investigated soil properties.

\begin{tabular}{lrrrrrrrrr}
\hline Variables & Clay & Silt & Sand & OM & MWD & $\mathrm{AS}_{1}$ & $\mathrm{AS}_{2}$ & $\mathrm{AS}_{3}$ & $\mathrm{FC}$ \\
\hline Silt & $\mathbf{0 . 4 1 4}$ & & & & & & & & \\
Sand & $-\mathbf{0 . 6 9 9}$ & $-\mathbf{0 . 9 0 0}$ & & & & & & & \\
OM & 0.056 & -0.005 & -0.034 & & & & & & \\
MWD & 0.651 & 0.152 & $-\mathbf{0 . 4 3 7}$ & $\mathbf{0 . 4 5 8}$ & & & & & \\
$\mathrm{AS}_{1}$ & 0.165 & 0.053 & -0.106 & $\mathbf{0 . 6 2 0}$ & $\mathbf{0 . 4 6 0}$ & & & & \\
$\mathrm{AS}_{2}$ & 0.097 & -0.062 & 0.015 & $\mathbf{0 . 5 5 0}$ & $\mathbf{0 . 4 0 2}$ & $\mathbf{0 . 8 7 1}$ & & & \\
$\mathrm{AS}_{3}$ & -0.034 & -0.100 & 0.121 & $\mathbf{0 . 4 8 5}$ & $\mathbf{0 . 2 3 0}$ & $\mathbf{0 . 8 3 0}$ & $\mathbf{0 . 8 4 5}$ & & \\
FC & $\mathbf{0 . 5 1 7}$ & $\mathbf{0 . 4 0 9}$ & $-\mathbf{0 . 5 5 6}$ & $\mathbf{0 . 6 0 4}$ & $\mathbf{0 . 7 5 7}$ & $\mathbf{0 . 5 4 8}$ & $\mathbf{0 . 4 5 6}$ & $\mathbf{0 . 2 9 8}$ & \\
WP & $\mathbf{0 . 5 3 5}$ & $\mathbf{0 . 4 6 0}$ & $-\mathbf{0 . 6 0 7}$ & $\mathbf{0 . 5 4 0}$ & $\mathbf{0 . 7 4 6}$ & $\mathbf{0 . 4 3 7}$ & $\mathbf{0 . 3 2 6}$ & 0.169 & $\mathbf{0 . 9 6 3}$ \\
\hline
\end{tabular}

Values in bold are different from 0 with a significance level alpha $=0.01$. MWD, mean weight diameter; OM, organic matter content; $\mathrm{AS}_{1}$, aggregate stability of $1.00-2.00 \mathrm{~mm}$ aggregate size; $\mathrm{AS}_{2}$, aggregate stability of $0.50-1.00 \mathrm{~mm}$ aggregate size;

$\mathrm{AS}_{3}$, aggregate stability of $0.25-0.50 \mathrm{~mm}$ aggregate size; $\mathrm{FC}$, water retention in $-33 \mathrm{kPa}$; WP, water retention in $-1500 \mathrm{kPa}$.

Table 4. Correlation coefficients between soil properties and factors.

\begin{tabular}{lrr}
\hline & $F 1$ & $F 2$ \\
\hline Clay & $\mathbf{0 . 5 4 5}$ & 0.447 \\
Silt & 0.388 & $\mathbf{0 . 5 5 3}$ \\
Sand & -0.578 & $-\mathbf{0 . 7 0 5}$ \\
MWD & $\mathbf{0 . 7 6 0}$ & 0.112 \\
OM & $\mathbf{0 . 6 1 2}$ & -0.325 \\
$\mathrm{AS}_{1}$ & $\mathbf{0 . 7 5 0}$ & -0.525 \\
$\mathrm{AS}_{2}$ & $\mathbf{0 . 6 5 4}$ & -0.603 \\
$\mathrm{AS}_{3}$ & 0.505 & $-\mathbf{0 . 6 5 5}$ \\
FC & $\mathbf{0 . 9 2 3}$ & 0.149 \\
$\mathrm{WP}$ & $\mathbf{0 . 8 6 6}$ & 0.266 \\
\hline
\end{tabular}

MWD, mean weight diameter; OM, organic matter content; $\mathrm{AS}_{1}$, aggregate stability of $1.00-2.00 \mathrm{~mm}$ aggregate size; $\mathrm{AS}_{2}$, aggregate stability of $0.50-1.00 \mathrm{~mm}$ aggregate size; $\mathrm{AS}_{3}$, aggregate stability of $0.25-0.50 \mathrm{~mm}$ aggregate size; FC, water retention in $-33 \mathrm{kPa}$; WP, water retention in $-1500 \mathrm{kPa}$.

tant factors affecting factor 1 , the silt content $(R=0.553)$, sand content $(R=-0.705)$, and $\mathrm{AS}_{3}(-0.655)$, had a great correlation with factor 2 (Table 4). While $\mathrm{AS}_{1}, \mathrm{AS}_{2}$ and $\mathrm{AS}_{3}$ were mainly determined by $\mathrm{OM}, \mathrm{FC}$ and WP were mainly determined by clay content, silt content, sand content and MWD. The AS values for each aggregate size were positively correlated with OM. In addition FC and WP were positively correlated with MWD, silt content, and clay content but negatively correlated with sand content (Fig. 5). The factor analysis results indicated that while the AS of alluvial soils was influenced mainly by the OM, their FC and WP were mostly determined by the MWD.

\subsection{Variance analysis results}

The difference between the sampling sites with respect to their clay contents was found to be statistically significant $(p<0.01)$. The lowest clay content was observed in L1 $(5.07 \%)$, which is also the youngest deposit area. L1 was followed, in increasing order of clay content, by L2 $(6.58 \%)$, L3 $(9.37 \%)$ and L4 $(10.27 \%)$, while L5, considered to be the oldest deposit area, had the highest clay content value (13.32\%; Table 5). The difference between the sampling sites with respect to their silt contents was also found to be statistically significant $(p<0.01)$. High silt content was observed in L5 $(34.91 \%)$, which was followed, in decreasing order of silt content, by L3 (31.18\%), L1 (27\%), L4 $(26.79 \%)$ and L2 (25. $73 \%$; Table 5). The sand content was found to vary significantly depending on the sampling site $(p<0.01)$. An evaluation of the multiple comparison tests reveals that high sand content was found in L1 $(67.91 \%)$ and L2 $(67.67 \%)$, followed by L4 (62.40\%), L3 (57.98\%) and L5 (51.13\%; Table 5).

The MWD of the soils was also found to vary significantly depending on the deposit area $(p<0.01)$. Study results indicated that the highest MWD values were observed in L5 $(0.82 \mathrm{~mm})$, followed by L4 $(0.77 \mathrm{~mm}), \mathrm{L} 3(0.65 \mathrm{~mm})$ and L2 $(0.56 \mathrm{~mm})$, with L1 having the lowest MWD $(0.35 \mathrm{~mm}$; Table 5).

AS values for the different aggregate classes $\left(\mathrm{AS}_{1}, \mathrm{AS}_{2}\right.$, $\mathrm{AS}_{3}$ ) were found to vary significantly depending on the deposit area $(p<0.01)$. $\mathrm{AS}_{1}$ values were higher in L2 $(90.95 \%)$ and L3 $(89.3 \%)$, where cultivation activities are minimal, while lower $\mathrm{AS}_{1}$ values were observed in areas of agricultural production, which are characterized by higher levels of plowing and cultivation activities (L4 and L5, with $\mathrm{AS}_{1}$ values of 86.67 and $83.60 \%$, respectively). AS values were the lowest in L1 sampling site $(58.51 \%)$, which is a young deposit area (Table 5).

The level of variation between FC of the sampling sites was found to be statistically significant $(p<0.01)$. Based on the study results, the highest FC was observed in L4 (35.59\%), which was followed by L5 (35.4\%), L3 (32.98\%) and L2 $(27.74 \%)$, with the lowest FC being observed in L1 (17.47\%; Table 5). The WP of the soils in different sampling 
Table 5. Summary of ANOVA for soil properties.

\begin{tabular}{lrrrrr}
\hline Properties & L1 & L2 & L3 & L4 & L5 \\
\hline Clay & $5.07^{\mathrm{D}} \pm 2.80$ & $6.58^{\mathrm{CD}} \pm 3.09$ & $9.37^{\mathrm{BC}} \pm 4.14$ & $10.27^{\mathrm{AB}} \pm 5.03$ & $13.32^{\mathrm{A}} \pm 4.27$ \\
Silt & $27.00^{\mathrm{B}} \pm 14.93$ & $25.73^{\mathrm{B}} \pm 4.88$ & $31.18^{\mathrm{AB}} \pm 6.63$ & $26.79^{\mathrm{B}} \pm 5.90$ & $34.91^{\mathrm{A}} \pm 6.12$ \\
Sand & $67.91^{\mathrm{A}} \pm 17.29$ & $67.67^{\mathrm{A}} \pm 6.67$ & $57.98^{\mathrm{BC}} \pm 8.32$ & $62.40^{\mathrm{AB}} \pm 10.18$ & $51.13^{\mathrm{C}} \pm 6.84$ \\
MWD & $0.35^{\mathrm{D}} \pm 0.06$ & $0.56^{\mathrm{C}} \pm 0.07$ & $0.65^{\mathrm{B}} \pm 0.13$ & $0.77^{\mathrm{A}} \pm 0.12$ & $0.82^{\mathrm{A}} \pm 0.08$ \\
$\mathrm{AS}_{1}$ & $58.51^{\mathrm{C}} \pm 9.01$ & $90.95^{\mathrm{A}} \pm 3.29$ & $89.13^{\mathrm{A}} \pm 4.53$ & $86.67^{\mathrm{AB}} \pm 4.65$ & $83.60^{\mathrm{B}} \pm 5.07$ \\
$\mathrm{AS}_{2}$ & $63.81^{\mathrm{C}} \pm 13.80$ & $89.91^{\mathrm{A}} \pm 4.18$ & $88.35^{\mathrm{AB}} \pm 6.62$ & $88.52^{\mathrm{AB}} \pm 4.31$ & $83.34^{\mathrm{B}} \pm 5.01$ \\
$\mathrm{AS}_{3}$ & $75.24^{\mathrm{C}} \pm 9.55$ & $91.56^{\mathrm{A}} \pm 2.73$ & $89.23^{\mathrm{A}} \pm 5.66$ & $84.23^{\mathrm{A}} \pm 3.43$ & $84.76^{\mathrm{B}} \pm 5.10$ \\
OM & $0.98^{\mathrm{B}} \pm 0.39$ & $3.31^{\mathrm{A}} \pm 1.02$ & $2.59^{\mathrm{A}} \pm 0.99$ & $3.10^{\mathrm{A}} \pm 1.25$ & $2.64^{\mathrm{A}} \pm 0.89$ \\
FC & $17.47^{\mathrm{C}} \pm 7.25$ & $27.74^{\mathrm{B}} \pm 5.74$ & $32.98^{\mathrm{A}} \pm 4.92$ & $35.59^{\mathrm{A}} \pm 7.55$ & $35.40^{\mathrm{A}} \pm 4.30$ \\
WP & $13.06^{\mathrm{C}} \pm 7.94$ & $19.20^{\mathrm{B}} \pm 4.26$ & $25.30^{\mathrm{A}} \pm 5.15$ & $27.98^{\mathrm{A}} \pm 7.30$ & $28.62^{\mathrm{A}} \pm 4.86$ \\
\hline
\end{tabular}

L1, L2, L3, L4 and L5 indicate sampling sites. Means with capital letters indicate significant difference of 0.01. MWD, mean weight diameter; $\mathrm{OM}$, organic matter content; $\mathrm{AS}_{1}$, aggregate stability of $1.00-2.00 \mathrm{~mm}$ aggregate size; $\mathrm{AS}_{2}$, aggregate stability of $0.50-1.00 \mathrm{~mm}$ aggregate size; $\mathrm{AS}_{3}$, aggregate stability of $0.25-0.50 \mathrm{~mm}$ aggregate size; $\mathrm{FC}$, water retention in $-33 \mathrm{kPa} ; \mathrm{WP}$, water retention in $-1500 \mathrm{kPa}$.

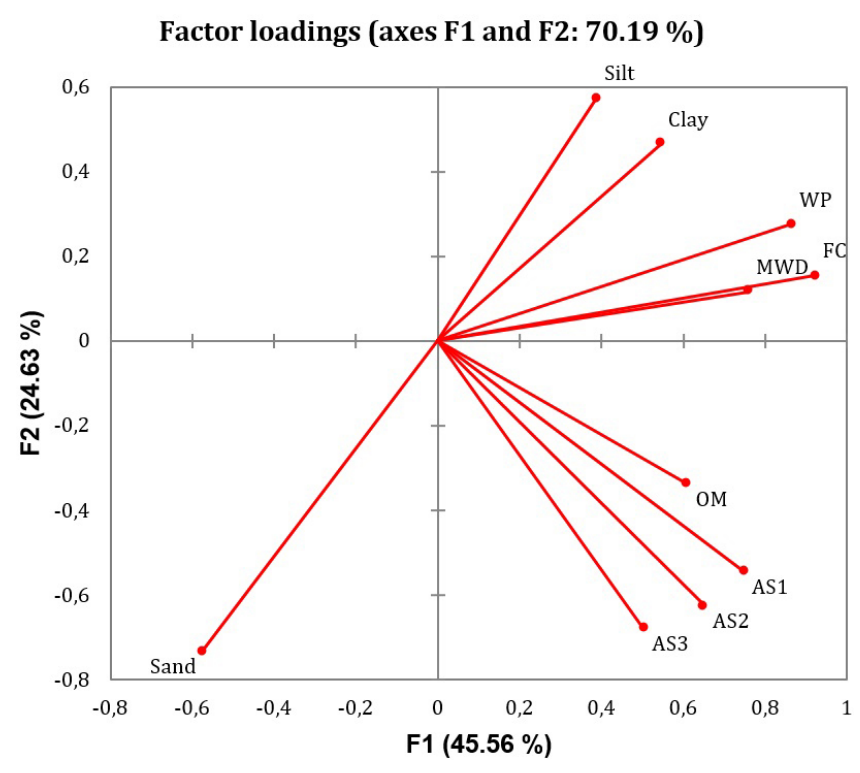

Figure 5. Factor analysis of studied soil properties in the Batumi delta (MWD, mean weight diameter; OM, organic matter content; $\mathrm{AS}_{1}$, aggregate stability of $1.00-2.00 \mathrm{~mm}$ aggregate size; $\mathrm{AS}_{2}$, aggregate stability of $0.50-1.00 \mathrm{~mm}$ aggregate size; $\mathrm{AS}_{3}$, aggregate stability of $0.25-0.50 \mathrm{~mm}$ aggregate size; FC, water retention in $-33 \mathrm{kPa}$; WP, water retention in $-1500 \mathrm{kPa}$ ).

sites also showed significant variation $(p<0.01)$. According to the study results, the highest WP was observed in L5 (28.62\%), which was followed by L4 (27.98\%), L3 (25.3\%) and L2 (19.2\%), with the lowest WP being observed in L1 $(13.06 \%)$.

Variance analysis results showed that the variation in the OM of the sampling sites was statistically significant $(p<0.01)$. Between the different sampling sites, the highest OM was observed in L2 (3.31\%), which was followed by L4 (3.1\%), L5 (2.64\%) and L3 (2.59\%). The lowest OM content was calculated for L1 (0.98\%; Table 5).

\section{Discussion}

It is observed that the information about the grain size distribution of the delta soil varied considerably in previous studies. The main cause of these differences was due to the difference in the parent material forming the delta soils, the formation conditions and the formation time. However, it was reported that delta soils predominantly had a higher sand content than silt and clay content (Elbasiouny et al., 2014; Li et al., 2015; He et al., 2017), which is similar to our study results. Although sampling areas had the same topography and the same climatic conditions, differences in land management and formation times resulted in high coefficient of variation of the studied properties. Similar to our findings, researchers reported that alluvial soil properties varied at significant levels resulting in higher standard deviation and coefficient of variation (Iqbal et al., 2005). In addition Saldana et al. (1998) reported that coefficient of variation for clay content was higher than silt and sand content, and for $\mathrm{pH}$ lower than other properties.

Assessments performed with the aim of determining soil aggregation have shown that soil fractions and OM content have varying effects on the MWD and AS. It was determined that clay, sand and OM content have a significant effect on the MWD of soils, while only OM has a significant effect on AS. It is known that aggregation occurs as a result of the reorganization, flocculation and binding soil particles (Duiker et al., 2003) and that this process is also mediated by the soil organic carbon, biota, ionic bridges, clay and carbonates (Bronick and Lal, 2005). According to Tisdall and Oades (1982), aggregates form sequentially based on a certain hierarchy, with different binding mechanisms being involved at every stage. In this hierarchy, clay, multivalent ions 
and organic materials congregate to form micro-aggregates $(<250 \mu \mathrm{m})$, and these constituents then congregate with other micro-aggregates to form macro-aggregates $(>250 \mu \mathrm{m}$; Tisdall, 1996). An increase in soil OM content also means an increase in the number of organic molecules that have a binding effect. The increase in the ratio of binding materials between particles results in a more solid aggregate structure. Based on these general observations, it is expected that an increase in clay content will be associated with an increase in MWD values, and $\mathrm{OM}$ will be associated with an increase in AS values. Similarly to our study results, other researchers have also reported positive correlations between the MWD and the clay (Chrenková et al., 2014), and MWD and OM content (Campo et al., 2014; Cheng et al., 2015; Zhang et al., 2016). In addition, certain researchers have also reported that the increase in OM leads to an increase in AS values (Aksakal et al., 2015; Obia et al., 2016; Simansky et al., 2016; Wang et al., 2016).

Soil particle size distribution, soil OM content, and bulk density are generally recognized as the most important factors affecting soil water retention (Liao et al., 2011; Botula et al., 2012; Yang et al., 2014). In this context, researchers reported that an increase in the clay and OM content also leads to an increase in water retention because of adsorptive effects of clay content, and affinity to water and influence on soil structure of OM (Hillel, 1971; Kirkham, 2004; Yang et al., 2014). In addition researchers stated that soil structure is also related to soil water retention (Pachepsky et al., 2006; Nguyen et al., 2015b; Hong et al., 2013; Khlosi et al., 2013). Our study findings are in agreement with these general observations, with the increase in clay and OM resulting in an increase in the amount of water retention at pressures of -33 (FC) and $-1500 \mathrm{kPa}(\mathrm{WP})$. In parallel with our study results, other researchers have also reported that an increase in clay content (Ding et al., 2016; Nguyen et al., 2015a; Obia et al., 2016) and OM content (Guo et al., 2016; Obia et al., 2016; Yang et al., 2014) is associated with an increase in field capacity and wilting point water content values. In a specific study, Rawls et al. (2003) reported that the effects of soil $\mathrm{OM}$ on soil water retention relied on the grain size distribution and the amount of soil OM. They also found that the increase in OM content led to an increase of water retention in sandy soils and to a decrease in fine-textured soils. Conflicting with their study results our study stated the fact that the effect of OM on FC and WP was found to be lower in soil with high sand content and higher in soil with high clay content.

It was observed that the clay content of the soil gradually increased moving from the active delta area towards the upper deltaic plain, while the sand content gradually decreased in the same direction. It is believed that there are two main underlying reasons for this variation: the first is the usage of the relevant areas, while the second is the morphological position of the sampling sites. Over the course of a delta's morphological development, new material is deposited in the active delta area, while the more inland areas will be converted into areas of agricultural production. It is known that the physical properties of coastal soils - such as soil particle size, aggregate and soil moisture - will eventually change as a result of reclamation actions such as plowing, irrigation and fertilization (Li et al., 2014). Similarly to our study results, other researchers also report that reclamation activities lead to a decrease in particle size ( $\mathrm{Li}$ et al., 2012; Sun et al., 2011). It is believed that seasonal variations in the flow regime of rivers that feed the delta especially cause clay-sized particles in the active delta section to be carried away. Studies on alluvial plains also report that areas closer to the riverbed have soils with higher sand content, while the soil sand content gradually decreases at increasing distances from the riverbed (Scott, 2000; Turgut and Öztaş, 2012). It is also believed that areas of deltas closer to the sea are more exposed to wave movement, which cause clay particles to be carried away from the delta by waves. In parallel with our study results, Yu et al. (2015) determined in their study on delta soils that the sand content was higher in soils closer to the sea and gradually decreased at increasing distances from the sea.

A prerequisite for aggregation is that the clay must be flocculated (Hillel, 2003); in the field, adjacent aggregates often tend to adhere to one another, though certainly not as strongly as do the particles within each aggregate. For this reason, it was expected that the lowest clay content would be observed in soils from L1 and that the MWD values for these soils would be the lowest. It was also expected that an increase in soil clay content would be associated with a higher MWD value. Similarly to our study results, other researchers have also reported that an increase in clay content for sandy soils led to an increase in MWD values (Chrenková et al., 2014; Wang et al., 2016).

AS is defined as the resistance exhibited by aggregate against mechanical shearing forces and the dispersing effect of water (Scott, 2000). Factors which affect the formation of stable aggregates within the soil include the wetting and drying cycle, the freezing and thawing cycle, and the presence of clay, $\mathrm{Fe}$ and/or $\mathrm{Al}$ oxides and $\mathrm{OM}$ in the soil (Abid and Lal, 2008; Karaman et al., 2007). AS values tend to increase in parallel with increasing OM content (Bravo-Garza et al., 2010; Joseph Oyedele et al., 1999; Plante and McGill, 2002a, b; Soinne et al., 2016; Tisdall and Oades, 1982). Soil cultivation activities, on the other hand, are known to reduce AS values (Jury and Horton, 2004; Plante and McGill, 2002a; Scott, 2000). The results of our study were generally in agreement with the literature, in that higher OM was found to be associated with higher AS, while areas subject to cultivation activities generally had lower AS. Other researchers similarly report a relationship between higher OM content and higher AS (Bravo-Garza et al., 2010; Soinne et al., 2016; Turgut et al., 2015), and the relationship between higher sand content and lower AS (Chrenková et al., 2014). Various researchers also report that soil cultivation has the effect of reducing AS 
(Plante and McGill, 2002b; Shu et al., 2015; Soinne et al., 2016).

The soil texture and structure affects the pore size and geometry of soils, which in turn affects their moisture constants. Owing to their high water retention capacity, and their ability to improve the structural properties of soils, OM also has a positive effect on the soil moisture values (Karaman et al., 2007). For this reason, areas with high MWD, clay content and OM content values are also expected to have high field capacity and wilting point moisture contents. In parallel with our study's findings, other researchers have also reported higher field capacity and wilting point moisture content with increasing OM (Bauer and Black, 1992; Hudson, 1994; Peake et al., 2014; Nguyen et al., 2015a) and clay content (Hudson, 1994; Rawls et al., 2003).

There are two main reasons for low OM content in coastal areas: the first is high salt content (Yuan et al., 2007) and the second is wave erosion (Wong et al., 2008). It is also known that vegetation has a direct effect on the soil OM content. Soil organic content is constituted of plant and animal remains (Baldock and Nelson, 2000; Karaman et al., 2007) and is directly associated with the plant biomass (Sollins et al., 1996; Jaiarree et al., 2011; Novara et al., 2013). It is believed in the present study that the lowest OM in L1, which is close to sea, is caused by coastal erosion, high salinity, and the sparsely distributed vegetation in this area. Vegetation in L2 consisted predominantly of bushes, which led to a higher $\mathrm{OM}$ in the area. In the other areas (L3, L4 and L5), it was observed that due to agricultural activities that accelerate the mineralization of OM, OM was lower compared to L2. Similarly to our study results, other researchers have also reported that the soil OM content of natural pastures and prairies was higher than that of areas used for cultivation (Cates et al., 2016; Gajić, 2013; Kodešová et al., 2011).

\section{Conclusions}

The results of this study clearly indicated that the main factors that caused high variations in soil properties in the $\mathrm{Ba}$ tumi delta (Georgia) were the differences in parent material due to physiographical positions and land use type. Most of the measured soil properties in this study were highly correlated with soil clay content and OM content. While soils in the active delta section that were mostly sandy textured (sandy loam, loamy sand and sand) took place at the west bottom corner of the textural triangle, soils in the upper delta plain were relatively medium textured (sandy loam and loam). Clay content of soil increased from the active delta section through the upper delta plain as a function of physiographical position, and the upper plain soil consisted of, on average, about 1.5 times more clay than that of the active delta section soil. On the other hand, soil OM content showed great variability because of land use type, producing the highest $\mathrm{OM}$ in grassland areas fallowed by cultivated land. Therefore it is concluded that the physiographical position and land use type should be considered in evaluation of the differentiations in delta plain soil characteristics. It is expected that the results of this study provide scientific data for land use management in the Batumi delta, which had never been studied before.

\section{Data availability}

The data resulting from this research were obtained by analyzing the soil samples taken by the authors of this article. You can see the detailed data in the Supplement.

\section{The Supplement related to this article is available online at doi:10.5194/se-8-1-2017-supplement.}

Edited by: M. van der Ploeg

Reviewed by: T. Askin and one anonymous referee

\section{References}

Abid, M. and Lal, R.: Tillage and drainage impact on soil quality: I. Aggregate stability, carbon and nitrogen pools, Soil. Till. Res., 100, 89-98, doi:10.1016/j.still.2008.04.012, 2008.

Aksakal, E. L., Sari, S., and Angin, I.: Effects of Vermicompost Application on Soil Aggregation and Certain Physical Properties, Land Degrad. Dev., 27, 983-995, doi:10.1002/ldr.2350, 2015.

Baldock, J. A. and Nelson, P.: Soil organic matter, in: Handbook of Soil Science, edited by: Sumner, M. E., CRC Press, Boca Raton, FL, USA, 2000.

Bauer, A. and Black, A. L.: Organic Carbon Effects on Available Water Capacity of Three Soil Textural Groups, Soil. Sci. Soc. Am. J., 56, 248-254, doi:10.2136/sssaj1992.03615995005600010038x, 1992.

Botula, Y.-D., Cornelis, W. M., Baert, G., and Van Ranst, E.: Evaluation of pedotransfer functions for predicting water retention of soils in Lower Congo (D.R. Congo), Agr. Water Manage. 111, 1-10, doi:10.1016/j.agwat.2012.04.006, 2012.

Bravo-Garza, M. R., Voroney, P., and Bryan, R. B.: Particulate organic matter in water stable aggregates formed after the addition of 14C-labeled maize residues and wetting and drying cycles in vertisols, Soil. Biol. Biochem., 42, 953-959, doi:10.1016/j.soilbio.2010.02.012, 2010.

Brevik, E. C., Cerdà, A., Mataix-Solera, J., Pereg, L., Quinton, J. N., Six, J., and Van Oost, K.: The interdisciplinary nature of SOIL, SOIL, 1, 117-129, doi:10.5194/soil-1-117-2015, 2015.

Bronick, C. J and Lal, R.: Soil structure and management: a review, Geoderma, 124, 3-22, doi:10.1016/j.geoderma.2004.03.005, 2005.

Campo, J., Gimeno-García, E., Andreu, V., González-Pelayo, O., and Rubio, J. L.: Cementing agents involved in the macro- and microaggregation of a Mediterranean shrubland soil under laboratory heating, Catena, 113, 165-176, doi:10.1016/j.catena.2013.10.002, 2014. 
Cates, A. M., Ruark, M. D., Hedtcke, J. L., and Posner, J. L.: Longterm tillage, rotation and perennialization effects on particulate and aggregate soil organic matter, Soil. Till. Res., 155, 371-380, doi:10.1016/j.still.2015.09.008, 2016.

Cheng, M., Xiang, Y., Xue, Z., An, S., and Darboux, F.: Soil aggregation and intra-aggregate carbon fractions in relation to vegetation succession on the Loess Plateau, China, Catena, 124, 77-84, doi:10.1016/j.catena.2014.09.006, 2015.

Chrenková, K., Mataix-Solera, J., Dlapa, P., and Arcenegui, $\mathrm{V}$.: Long-term changes in soil aggregation comparing forest and agricultural land use in different Mediterranean soil types, Geoderma, 235-236, 290-299, doi:10.1016/j.geoderma.2014.07.025, 2014.

Cui, J., Liu, C., Li, Z., Wang, L., Chen, X., Ye, Z., and Fang, C.: Long-term changes in topsoil chemical properties under centuries of cultivation after reclamation of coastal wetlands in the Yangtze Estuary, China, Soil. Till. Res., 123, 50-60, doi:10.1016/j.still.2012.03.009, 2012.

Decock, C., Lee, J., Necpalova, M., Pereira, E. I. P., Tendall, D. M., and Six, J.: Mitigating $\mathrm{N}_{2} \mathrm{O}$ emissions from soil: from patching leaks to transformative action, SOIL, 1, 687-694, doi:10.5194/soil-1-687-2015, 2015.

Deng, L., Wang, G.-1., Liu, G.-B., and Shangguan, Z.-P.: Effects of age and land-use changes on soil carbon and nitrogen sequestrations following cropland abandonment on the Loess Plateau, China. Ecol. Eng., 90, 105-112, doi:10.1016/j.ecoleng.2016.01.086, 2016.

Dilkova, R., Jokova, M., Kerchev, G., and Kercheva, M.: Aggregate stability as a soil quality criterion, in: Proceeding of the 7 . International Meeting on Soils with Mediterranean Type of Climate, Bari, Italy, 23-28 September 2001, 50, 305-312, 2002.

Ding, D., Zhao, Y., Feng, H., Peng, X., and Si, B.: Using the doubleexponential water retention equation to determine how soil poresize distribution is linked to soil texture, Soil Till. Res., 156, 119130, doi:10.1016/j.still.2015.10.007, 2016.

Duiker, S. W, Rhoton, F. E., Torrent, J., Smeck, N. E., and Lal, R.: Iron (hydr)oxide crystallinity effects on soil aggregation, Soil Sci. Soc. Am. J., 67, 606-611, 2003.

Elbasiouny, H., Abowaly, M., AbuAlkheir, A. and Gad, A.: Spatial variation of soil carbon and nitrogen pools by using ordinary Kriging method in an area of north Nile Delta, Egypt, Catena, 113, 70-78, doi:10.1016/j.catena.2013.09.008, 2014.

Erinç, S.: Jeomorfoloji 2, Der Press, İstanbul, Türkiye, 2001 (in Turkish).

Gajić, B.: Physical properties and organic matter of Fluvisols under forest, grassland, and 100 years of conventional tillage, Geoderma, 200-201, 114-119, doi:10.1016/j.geoderma.2013.01.018, 2013.

Gee, G. W. and Bauder, J. W.: Particle-size analysis, in: Methods of soil analysis, Part 1. Physical and mineralogical methods. American Society of Agronomy, edited by: Klute, A., Inc., Madison, Wisconsin, 383-411, 1986.

Gillison, A. N., Asner, G. P., Fernandes, E. C. M., Mafalacusser, J., Banze, A., Izidine, S., de Fonseca, A. R., and Pacate, H.: Biodiversity and agriculture in dynamic landscapes: Integrating ground and remotely-sensed baseline surveys, J. Environ. Manage., 177, 9-19, doi:10.1016/j.jenvman.2016.03.037, 2016.

Guo, L., Wu, G., Li, Y., Li, C., Liu, W., Meng, J., Liu, H., Yu, X., and Jiang, G.: Effects of cattle manure compost combined with chemical fertilizer on topsoil organic matter, bulk density and earthworm activity in a wheat-maize rotation system in Eastern China, Soil Till. Res., 156, 140-147, doi:10.1016/j.still.2015.10.010, 2016.

Han, G., Xing, Q., Yu, J., Luo, Y., Li, D., Yang, L., Wang, G., Mao, P., Xie, B., and Mikle, N.: Agricultural reclamation effects on ecosystem $\mathrm{CO}_{2}$ exchange of a coastal wetland in the Yellow River Delta, Agr. Ecosys. Environ., 196, 187-198, doi:10.1016/j.agee.2013.09.012, 2014.

Hernández, Á., Arellano, E. C., Morales-Moraga, D., and Miranda, M. D.: Understanding the effect of three decades of land use change on soil quality and biomass productivity in a Mediterranean landscape in Chile, Catena, 140, 195-204, doi:10.1016/j.catena.2016.01.029, 2016.

He, F., Yinghua, P., Lili, T., Zhenhua, Z., Peng, L., Jia, L., Shuxin, J., Zhaohua, Q., Hongbo, S., and Xueyan, S.: Study of the water transportation characteristics of marsh saline soil in the Yellow River Delta, Sci. Total Environ., 574, 716-23, doi:10.1016/j.scitotenv.2016.09.111, 2017.

Hillel, D.: Physical Principles and Processes, Academic Press, Inc., New York, USA, 1971.

Hillel, D.: Introduction to environmental soil physics, Academic Press, Burlington, MA, USA, 2003.

Hong, S. Y., Minasny, B., Han, K. H., Kim, Y., and Lee, K.: Predicting and mapping soil available water capacity in Korea, PeerJ, 1, e71, doi:10.7717/ peerj.71, 2013.

Huang, L., Bai, J., Chen, B., Zhang, K., Huang, C., and Liu, P.: Two-decade wetland cultivation and its effects on soil properties in salt marshes in the Yellow River Delta, China. Ecol. Inform., 10, 49-55, doi:10.1016/j.ecoinf.2011.11.001, 2012.

Hudson, B. D.: Soil organic matter and available water capacity, J. Soil Water Conserv., 49, 189-194, 1994.

Iqbal, J., Thomasson, J. A., Jenkins, J. N., Owens, P. R., and Whisler, F. D.: Spatial variability analysis of soil physical properties of alluvial soils this study was in part supported by the national aeronautical and space administration funded remote sensing technology center at Mississippi State University, Soil. Sci. Soc. Am. J., 69, 1-13, 2005.

Imentai, A., Thevs, N., Schmidt, S., Nurtazin, S., and Salmurzauli, R.: Vegetation, fauna, and biodiversity of the Ile Delta and southern Lake Balkhash-A review, J. Great Lakes Res., 41, 688-696, doi:10.1016/j.jglr.2015.04.002, 2015.

Jaiarree, S., Chidthaisong, A., Tangtham, N., Polprasert, C., Sarobol, E., and Tyler, S. C.: Carbon budget and sequestration potential in a sandy soil treated with compost, Land Degrad. Dev., 25, 120-129, doi:10.1002/ldr.1152, 2011.

Jiao, S., Zhang, M., Wang, Y., Liu, J., and Li, Y.: Variation of soil nutrients and particle size under different vegetation types in the Yellow River Delta, Acta Ecologica Sinica, 34, 148-153, doi:10.1016/j.chnaes.2014.03.003, 2014.

JMP: JMP, Version 5.0, SAS Institute Inc., Cary, NC, USA, 19892007.

Joseph Oyedele, D., Schjønning, P., Sibbesen, E., and Debosz, K.: Aggregation and organic matter fractions of three Nigerian soils as affected by soil disturbance and incorporation of plant material, Soil. Till. Res., 50, 105-114, doi:10.1016/S01671987(98)00200-1, 1999.

Jury, W. A. and Horton, R.: Soil physics, John Wiley \& Sons, Inc., Hoboken, NewJersey, USA, 2004. 
Karaman, M., Brohi, A., Müftüoğlu, N., Öztaş, T., and Zengin, M.: Sürdürülebilir torak verimliliği, Detay Press, Ankara, Turkey, 2007 (in Turkis).

Keesstra, S. D., Bouma, J., Wallinga, J., Tittonell, P., Smith, P., Cerdà, A., Montanarella, L., Quinton, J. N., Pachepsky, Y., van der Putten, W. H., Bardgett, R. D., Moolenaar, S., Mol, G., J ansen, B., and Fresco, L. O.: The significance of soils and soil science towards realization of the United Nations Sustainable Development Goals, SOIL, 2, 111-128, doi:10.5194/soil-2-1112016, 2016.

Kemper, W. and Rosenau, R.: Aggregate Stability and Size Distribution, in: Methods of Soil Analysis: Part I: Physical and Minerological Methods, edited by: Black, C. A., Evans, D. D., and Dinauer, R. C., American Society of Agronomy, Madison, USA, 1986.

Khai, H. V. and Yabe, M.: Consumer preferences for agricultural products considering the value of biodiversity conservation in the Mekong Delta, Vietnam, J. Nat. Conserv., 25, 62-71, doi:10.1016/j.jnc.2015.02.004, 2015.

Khlosi, M., Cornelis, W. M., Douaik, A., Hazzouri, A., Habib, H., and Gabriels, D.: Exploration of the interaction between hydraulic and physicochemical properties of Syrian soils, Vadose Zone J., 12, doi:10.2136/vzj2012.0209, 2013.

Kirkham, M. B.: Principles of soil and plant water relations, Academic Press, Oxford, UK, 2004.

Kodešová, R., Jirků, V., Kodeš, V., Mühlhanselová, M., Nikodem, A., and Žigová, A.: Soil structure and soil hydraulic properties of Haplic Luvisol used as arable land and grassland, Soil Till. Res., 111, 154-161, doi:10.1016/j.still.2010.09.007, 2011.

Krishnamoorthy, R., Kim, K., Kim, C., and Sa, T.: Changes of arbuscular mycorrhizal traits and community structure with respect to soil salinity in a coastal reclamation land, Soil Biol. Biochem., 72, 1-10, doi:10.1016/j.soilbio.2014.01.017, 2014.

Li, X., Sun, Y., Mander, Ü., and He, Y.: Effects of land use intensity on soil nutrient distribution after reclamation in an estuary landscape, Landscape Ecol., 28, 699-707, doi:10.1007/s10980012-9796-2, 2012.

Li, J., Pu, L., Zhu, M., Zhang, J., Li, P., Dai, X., Xu, Y., and Liu, L.: Evolution of soil properties following reclamation in coastal areas: A review, Geoderma, 226-227, 130-139, doi:10.1016/j.geoderma.2014.02.003, 2014.

Li, Y., Haibo, Z., Chen, T., Fang, S., and Yongming L.: Occurrence of Red Clay Horizon in Soil Profiles of the Yellow River Delta: Implications for Accumulation of Heavy Metals, J. Geochem. Explor., in press, doi:10.1016/j.gexplo.2015.11.006, 2015.

Liao, K-H., Xu, S-H., Wu, J-C., Ji, S.-H., and Lin, Q.: Assessing soil water retention characteristics and their spatial variability using pedotransfer functions, Pedosphere, 21, 413-22, doi:10.1016/S1002-0160(11)60143-4, 2011.

Madhavan, D. B., Kitching, M., Mendham, D. S., Weston, C. J., and Baker, T. G.: Mid-infrared spectroscopy for rapid assessment of soil properties after land use change from pastures to Eucalyptus globulus plantations, J. Environ. Manage., 175, 6775, doi:10.1016/j.jenvman.2016.03.032, 2016.

Marchetti, A., Piccini, C., Francaviglia, R., and Mabit, L.: Spatial distribution of soil organic matter using geostatistics: A key indicator to assess soil degradation status in central Italy, Pedosphere, 22, 230-242, doi:10.1016/S1002-0160(12)60010-1, 2012.
Nguyen, P. M., Van, Le K., Botula, Y.-D., and Cornelis, W. M.: Evaluation of soil water retention pedotransfer functions for Vietnamese Mekong Delta soils, Agr. Water Manage., 158, 126-138, doi:10.1016/j.agwat.2015.04.011, 2015a.

Nguyen, P. M., Pue, J. D., Van Le, K., and Cornelis. W.: Impact of regression methods on improved effects of soil structure on soil water retention estimates, J. Hydrol., 525, 598-606, doi:10.1016/j.jhydrol.2015.04.014, 2015b.

Novara, A., Gristina, L., Rühl, J., Pasta, S., D’Angelo, G., La Mantia, T., and Pereira, P.: Grassland fire effect on soil organic carbon reservoirs in a semiarid environment, Solid Earth, 4, 381-385, doi:10.5194/se-4-381-2013, 2013.

Obia, A., Mulder, J., Martinsen, V., Cornelissen, G., and Børresen, T.: In situ effects of biochar on aggregation, water retention and porosity in light-textured tropical soils, Soil Till. Res., 155, 3544, doi:10.1016/j.still.2015.08.002, 2016.

Peake, L. R., Reid, B. J., and Tang, X.: Quantifying the influence of biochar on the physical and hydrological properties of dissimilar soils, Geoderma, 235-236, 182-190, doi:10.1016/j.geoderma.2014.07.002, 2014.

Plante, A. F. and McGill, W. B.: Soil aggregate dynamics and the retention of organic matter in laboratory-incubated soil with differing simulated tillage frequencies, Soil Till. Res., 66, 79-92, doi:10.1016/S0167-1987(02)00015-6, 2002a

Plante, A. F. and McGillb, W. B.: Intraseasonal soil macroaggregate dynamics in two contrasting field soils using labeled tracer spheres, Soil Sci. Soc. Am. J., 66, 1285-1295, doi:10.2136/sssaj2002.1285, 2002b.

Rawls, W. J., Pachepsky, Y. A., Ritchie, J. C., Sobecki, T. M., and Bloodworth, H.: Effect of soil organic carbon on soil water retention, Geoderma, 116, 61-76, doi:10.1016/S00167061(03)00094-6, 2003.

Saldana, A., Stein, A., and Zinck, J. A.: Spatial variability of soil properties at different scales within three terraces of the Henares River (Spain), Catena, 33, 139-153, 1998.

Schnitzer, M.: Total carbon, organic matter, and carbon, American Society of Agronomy, Madison, USA, 1982.

Scott, H. D.: Soil Physics: Agriculture and Environmental Applications, Iowa State University Press, Iowa, USA, 2000.

Shu, X., Zhu, A.-N., Zhang, J.-B., Yang, W.-L., XIN, X.-L., and Zhang, X.-F.: Changes in soil organic carbon and aggregate stability after conversion to conservation tillage for seven years in the Huang-Huai-Hai Plain of China, Journal of Integrative Agriculture, 14, 1202-1211, doi:10.1016/S2095-3119(14)60862-5, 2015.

Simansky, V., Balashov, E., and Horak, J.: Water stability of soil aggregates and their ability to sequester carbon in soils of vineyards in Slovakia, Arch. Acker Pfl. Boden., 62, 177-197, doi:10.1080/03650340.2015.1048683, 2016.

Smith, P., Cotrufo, M. F., Rumpel, C., Paustian, K., Kuikman, P. J., Elliott, J. A., McDowell, R., Griffiths, R. I., Asakawa, S., Bustamante, M., House, J. I., Sobocká, J., Harper, R., Pan, G., West, P. C., Gerber, J. S., Clark, J. M., Adhya, T., Scholes, R. J., and Scholes, M. C.: Biogeochemical cycles and biodiversity as key drivers of ecosystem services provided by soils, SOIL, 1, 665685, doi:10.5194/soil-1-665-2015, 2015.

Soinne, H., Hyväluoma, J., and Ketoja, E., and Turtola, E.: Relative importance of organic carbon, land use and moisture con- 
ditions for the aggregate stability of post-glacial clay soils, Soil Till. Res., 158, 1-9, doi:10.1016/j.still.2015.10.014, 2016.

Sollins, P., Homann, P., and Caldwell, B. A.: Stabilization and destabilization of soil organic matter: mechanisms and controls, Geoderma, 74, 65-105, doi:10.1016/S0016-7061(96)00036-5, 1996.

Søvik, A. K. and Aagaard, P.: Spatial variability of a solid porous framework with regard to chemical and physical properties, Geoderma, 113, 47-76, doi:10.1016/S0016-7061(02)00315-4, 2003.

Sun, Y., Li, X., Mander, Ü., He, Y., Jia, Y., Ma, Z., Guo, W., and Xin, Z.: Effect of reclamation time and land use on soil properties in Changjiang River Estuary, China. Chinese Geogr. Sci., 21, 403416, doi:10.1007/s11769-011-0482-0, 2011.

Tisdall, J.: Formation of soil aggregates and accumulation of soil organic matter, in: Structure and Organic Matter Storage in Agricultural Soils, edited by: Carter, M. R. and Stewart, B. A., Lewis Publishers, New York, USA, 1996.

Tisdall J. M. and Oades, J. M.: Organic matter and water-stable aggregates in soils, J. Soil Sci., 33, 141-163, 1982.

Turgut, B. and Öztaş, T.: Assessment of spatial distribution of some soil properties with geostatistics method, Süleyman Demirel University Journal of the Faculty of Agriculture, 7, 10-22, 2012.

Turgut, B., Ozalp, M., and Kose, B.: Physical and chemical properties of recently deposited sediments in the reservoir of the Borcka Dam in Artvin, Turkey, Turk. J. Agric. For., 39, 663-678, doi:10.3906/tar-1404-60, 2015.

Unverricht, D., Szczuciński, W., Stattegger, K., Jagodziński, R., Le, X. T., and Kwong, L. L. W.: Modern sedimentation and morphology of the subaqueous Mekong Delta, Southern Vietnam, Global Planet. Change, 110, 223-235, doi:10.1016/j.gloplacha.2012.12.009, 2013.
Van Bavel, C.: Mean weight-diameter of soil aggregates as a statistical index of aggregation, Soil Sci. Soc. Am. J., 14, 20-23, 1950.

Wang, J.-G., Yang, W., Yu, B., Li, Z.-X., Cai, C.-F., and Ma, R.M.: Estimating the influence of related soil properties on macroand micro-aggregate stability in ultisols of south-central China, Catena, 137, 545-553, doi:10.1016/j.catena.2015.11.001, 2016.

Wong, V. N. L., Murphy, B. W., Koen, T. B., Greene, R. S. B., and Dalal, R. C.: Soil organic carbon stocks in saline and sodic landscapes, Aust. J. Soil Res. 46, 378-389, 2008.

Yang, F., Zhang, G.-L., Yang, J.-L., Li, D.-C., Zhao, Y.-G., Liu, F., Yang, R.-M., and Yang, F.: Organic matter controls of soil water retention in an alpine grassland and its significance for hydrological processes, J. Hydrol., 519, 3086-3093, doi:10.1016/j.jhydrol.2014.10.054, 2014.

Yu, J., Lv, X., Bin, M., Wu, H., Du, S., Zhou, M., Yang, Y., and Han, G.: Fractal features of soil particle size distribution in newly formed wetlands in the Yellow River Delta, Sci. Rep., 5, 1-9, doi:10.1038/srep10540, 2015.

Yuan, B., Li, Z., Liu, H., Gaob, M., and Zhang, Y.; Microbial biomass and activity in salt af- fected soils under arid conditions, Appl. Soil Ecol., 35, 319-328, 2007.

Zhang, Z. B., Zhou, H., Lin, H., and Peng, X.: Puddling intensity, sesquioxides, and soil organic carbon impacts on crack patterns of two paddy soils, Geoderma, 262, 155-164, doi:10.1016/j.geoderma.2015.08.030, 2016. 